Article

\title{
Karakteristik Bioplastik Kitosan-Onggok Aren (Arenga pinnata) dengan Penambahan Serbuk Kunyit
}

\author{
Suwardi ${ }^{1}$, Nur Hidayati ${ }^{2}$ \\ Program Studi Teknik Kimia, Fakultas Teknik, Universitas Muhammadiyah Surakarta \\ Jl. A. Yani Tromol Pos 1 Pabelan Kartasura Surakarta \\ E-mail: nur.hidayati@ums.ac.id
}

\begin{abstract}
Bioplastics are organic plastics which one of their functions can be used as food packaging. Bioplastics are known to be environmentally friendly because they are easily degraded by nature. Chitosan can be modified with onggok palm starch in making bioplastics to increase the strength of the bioplastics. The addition of turmeric to the chitosan-onggok bioplastic is expected to increase resistance to microbes so that the bioplastic can be used as a food packaging material. This study aims to determine the bioplastic characteristics of chitosan-onggok palm sugar added with turmeric with a variation of $0.3-1.2 \%$. Physical tests carried out include water absorption test, tensile strength test, elongicity test and biodegradation test. The increase in the amount of turmeric in water increases its water absorption, tensile strength and biodegradation properties, while the decrease in plastic elongation decreases with the increase in the amount of turmeric in the plastic.
\end{abstract}

Keywords: Bioplastics, starch, onggok, turmeric, characteristics

EQUILIBRIUM Volume 4 No.2 December 2020

Online at http://equilibrium.ft.uns.ac.id 


\section{Pendahuluan}

Semakin majunya teknologi dan industri akan diikuti dengan semakin meningkatnya konsumsi masyarakat pada bahan-bahan plastik yang menyebabkan penumpukan sampah plastik. Berdasarkan data statistik yang diperoleh dari Kementrian Negara Lingkungan Hidup Republik Indonesia (KNLH) pada tahun 2008 mengenai persampahan domestik Indonesia, sampah plastik menempati urutan kedua setelah sampah dapur sebesar $14 \%$ dari jumlah sampah total diperkirakan akan meningkat 5,4 juta ton per tahunnya (Agustin dkk., 2016).

Usaha pengurangan jumlah sampah plastik telah banyak dilakukan, diantara program "Reduce, Reuse and Recycling" (3R). Pembuatan plastik yang mudah terurai/biodegradable menawarkan solusi yang menarik. Bioplastik merupakan istilah untuk plasti yang mudah terurai secara alamiah karena mudah terdegradasi baik melalui serangan mikroorganisme maupun oleh cuaca (kelembaban dan radiasi sinar matahari). Bioplastik terbuat dari material yang dapat diperbarui, yaitu dari senyawa-senyawa yang terdapat dalam tanaman misalnya selulosa, kolagen, kasein, protein atau lipid yang terdapat dalam hewan. Jenis bioplastik antara lain polyhidroksialkanoat (PHA) dan poli-asam amino yang berasal dari sel bakteri, polylaktida (PLA) yang merupakan modifikasi asam laktat hasil perubahan zat tepung kentang atau jagung oleh mikroorganisme, dan poliaspartat sintesis yang dapat terdegradasi. Bahan dasar plastik berasal dari selulosa bakteri, dan kitin, kitosan, atau tepung ynag terkandung dalam tumbuhan, serta beberapa material bioplastik atau polimer lain yang terdapat di sel tumbuhan dan hewan. Plastik dengan bahan baku berupa polimer sintetis membutuhkan waktu sekitar 50 tahun agar dapat terdekomposisi 10 hingga 20 kali lebih cepat. Hasil degradasi plastik ini dapat digunakan sebagai makanan hewan ternak atau sebagai pupuk kompos. Bioplastik yang terbakar tidak menghasilkan senyawa kimia yang berbahaya. Kualitas tanah akan meningkat dengan adanya bioplastik, karena hasil penguraian mikroorganisme meningkatkan unsur hara dalam tanah (Coniwanti dkk., 2014).

Tepung atau pati merupakan jenis polimer yang secara alami diproduksi oleh tumbuhan jenis umbiumbian, jagung dan beras (umumnya, pati terdapat pada tanaman yang banyak mengandung karbohidrat) dalam bentuk butiran halus. Pati onggok juga dikenal cassava waste dikenal sebagai bahan bioplastik paling efektif karena merupakan bahan alami yang murah serta dapat terdegradasi dengan sangat cepat. Kandungan pati yang berasal dari ampas onggok aren ini mengandung selulosa $95,34 \%$, bahan kering $85,8 \%$, protein kasar 2,63\%, serat kasar 15,90\%, dan lemak kasar 0,48\% (Nurlita dkk., 2011).

Penambahan bahan polimer yang bersifat elastik perlu dilakukan untuk memperbaiki karakteristik mekanik pada bioplastik. Salah satu bahan yang daoat digunakan ialah kitosan. Kitosan merupakan jenis polisakarida yang dapat digunakan sebagai bioplastik. Kitosan juga memiliki sifat mekanik yang memadai serta penghalang yang baik terhadap oksigen dan aroma (Abugoch., 2011).

Kunyit atau curcuma longa linn adalah salah satu tanaman rempah-rempah dan obat asli. Kunyit mengandung kurkominoid yang terdiri dari kurkumin, desmetoksikumin sebanyak 10\% dan bisdesmetoksi kurkumin sebanyak $1-5 \%$ dan zat-zat yang bermanfaat lainnya seperti minyak atsiri yang terdiri dari keton sesquiterpen, turmeron, tumeon $60 \%$, zingiberen $25 \%$, falendren, sabien, dan sineil. Kunyit juga mengandung lemak sebanyak $1-3 \%$, karbohidrat $3 \%$, protein $30 \%$, pati $8 \%$, vitamin C $45-55 \%$, dan garam mineral. Kunyit juga dapat digunakan sebagai bahan pembuatan bioplastik sebagai pengikat oksidan dan antibakteri (Aprianda dkk., 2018).

Kombinasi pati onngok dan kitosan diharapkan dapat menghasilkan plastik yang kuat tapi ramah lingkungan. Penambahan kunyit ke dalam bahan plastik tersebut ditujukan untuk memperbaiki sifat plastik yaitu anti bakteri terutama untuk aplikasi sebagai bahan kemasan makanan. Tujuan penelitian ini untuk mengkaji efek banyaknya serbuk kunyit yang ditambahkan ke dalam plastik kitosan-onggok aren. Variable bebas yang diuji adalah banyaknya serbuk kunyit yang diari tambahkan ke dalam film bioplastik $(0,3 \%, 0,6 \%$, $0,9 \%, 1,2 \%)$. Respon yang diuji meliputi sifat ketahan air, elongisitas, kuat tarik dan biodegradasi. Sedangkan variabel kontrolnya adalah perbandingan pati onggok aren dan kitosan (50:50).

\section{Metode Penelitian}

\subsection{Bahan}

Bahan yang diperlukan dalam penelitian ini adalah pati onggok aren diperoleh dari industri rumahan di daerah klaten, kitosan diperoleh dari IPB, asam asetat dan gliserol dari Merck, dan serbuk kunyit dari toko lokal. 


\subsection{Tahap Persiapan Preparasi Pati dari Onggok Aren}

Onggok aren terlebih dahulu dikeringkan, Setelah itu ditumbuk hingga halus agar mudah tercampur dengan larutan.

\subsection{Sintesis Film Pati, Kitosan, dan Kunyit}

Pembuatan larutan kitosan dilakukan dengan cara melarutkan 5 gram serbuk kitosan ke dalam larutan asam asetat $2 \%$ sebanyak $250 \mathrm{~mL}$. Selanjutnya, serbuk pati onggok ditambahkan ke dalam larutan kitosan sambil diaduk selama 1 jam pada suhu $60^{\circ} \mathrm{C}$. Gliserol sebanyak $2 \mathrm{~mL}$ dan kunyit sejumlah tertentu ditambahkan. Pengadukan dilanjutkan agar larutan homogen. Kemudian larutan dicetak pada permukaan plat kaca, dan masukan ke dalam oven untuk menghilangkan air dan terjadi ikatan silang antar polimer pada suhu $60^{\circ} \mathrm{C}$ selama 1 hari.

\section{Hasil dan Pembahasan}

Bioplastik dibuat dengan mencampurkan kitosan, pati serat onggok dan tepung kunyit. Gliserol ditambahkan sebagai bahan pemlastik agar terjadi ikatan silang pada polimer yang dihasilkan. Bioplastik yang dihasilkan dalam penelitian ini memiliki ketebalan $0,01 \mathrm{~mm}$. Intensitas warna bioplastik yang dihasilkan menyesuaikan dengan banyaknya kunyit yang ditambahkan.

\subsection{Uji Ketahan Air}

Uji ketahanan air dilakukan untuk mengetahui terjadinya ikatan dalam polimer serta tingkatan atau keteraturan ikatan dalam polimer yang ditentukan melalui adanya penambahan berat polimer setelah mengalami penggembungan dengan adanya molekul air dalam lembaran film. Jika dibandingkan dengan penelitian bioplastik pati sorgum dan kitosan (Darni, et al., 2009) dalam penelitian tersebut diperoleh ketahanan air yang dihasilkan sebesar 36,8\%. Gambar 1 menunjukkan efek banyaknya kunyit yang ditambahkan ke dalam bioplastik kitosan-pati onggok aren terhadap ketahanan air.

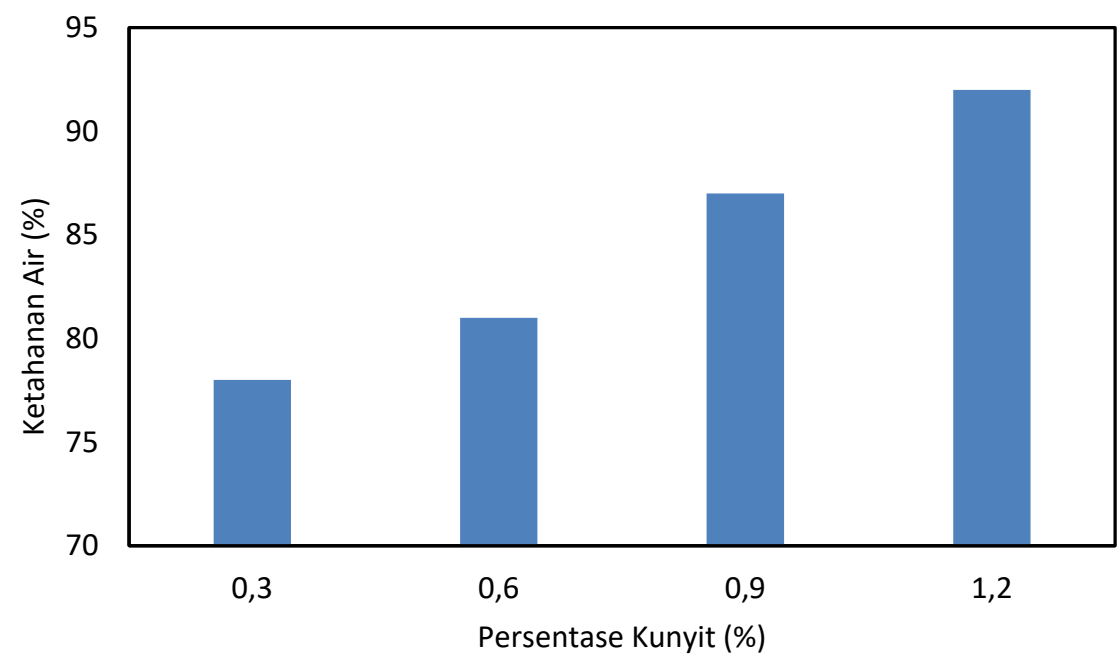

Gambar 1. Persentase Ketahanan Air Film berbagai variasi penambahan kunyit

Secara umum peningkatan banyaknya serbuk kunyit dalam plastik kitosan-pati onggok meningkatkan sifat ketahanan air plastik (Gambar 1.) Penambahan serbuk kunyit sebanyak $0,3 \%$ menghasilkan bioplastik dengan nilai ketahanan air sebanyak $78 \%$. Nilai ketahanan air tertinggi dimiliki oleh plastik dengan kunyit sebanyak $1,2 \%$ di dalamnya. 


\subsection{Uji Kuat Tarik}

Kuat tarik adalah gaya tarik maksimum yang dapat ditahan oleh lembaran plastik selama pengukuran berlansung. Kekuatan maksimum yang dimaksud merupakan tegangan maksimum yang dapat dicapai pada diagram tegangan suatu regangan. Tegangan ini terjadi karena adanya fenomena pengecilan pada benda uji yang berlanjut hingga benda putus atau patah. Pada uji kekuatan tarik ini, dapat diketahui bagaimana bahan tersebut bereaksi terhadap tenaga tarikan dan mengetahui sejauh mana material itu bertambah panjang (Darni dkk, 2014). Gambar 2 merupakan data pengaruh banyaknya kunyit yang ditambahkan ke dalam bioplastik kitosan-pati onggok aren terhadap kuat tarik.

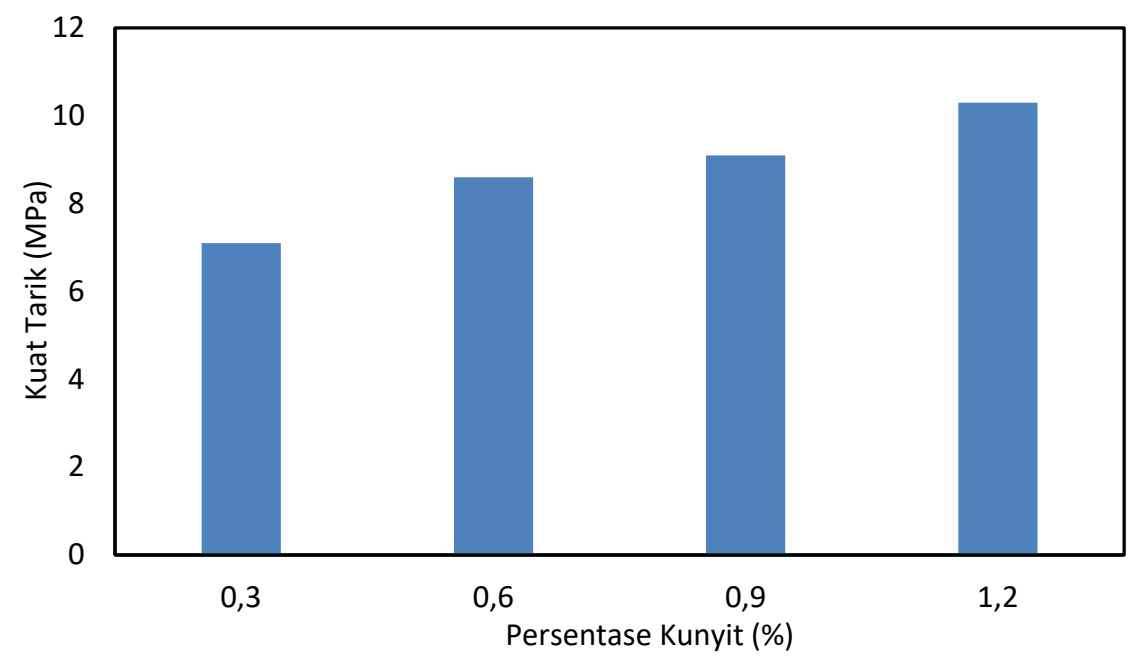

Gambar 2. Persentase Kuat Tarik Film berbagai variasi penambahan kunyit

Data berdasarkan Gambar 2 menjelaskan bahwa kuat tarik bioplastik kitosan-pati onggok dipengaruhi secara positif oleh banyaknya serbuk kunyit yang ditambahkan, meskipun peningkatan kuat tarik tidak begitu signifikan, yaitu pada nilai sekitar 7,0-8,8 MPa. Penelitian sejenis menunjukkan bahwa kuat tarik plastik kitosan-pati onggok pada nilai 1,22 MPa (Nurlita dkk, 2011). Penambahan kunyit rupanya dapat meningkatkan kuat tarik, walaupun ada variabel lainnya yang dapat mempengaruhinya.

\subsection{Uji Kemuluran}

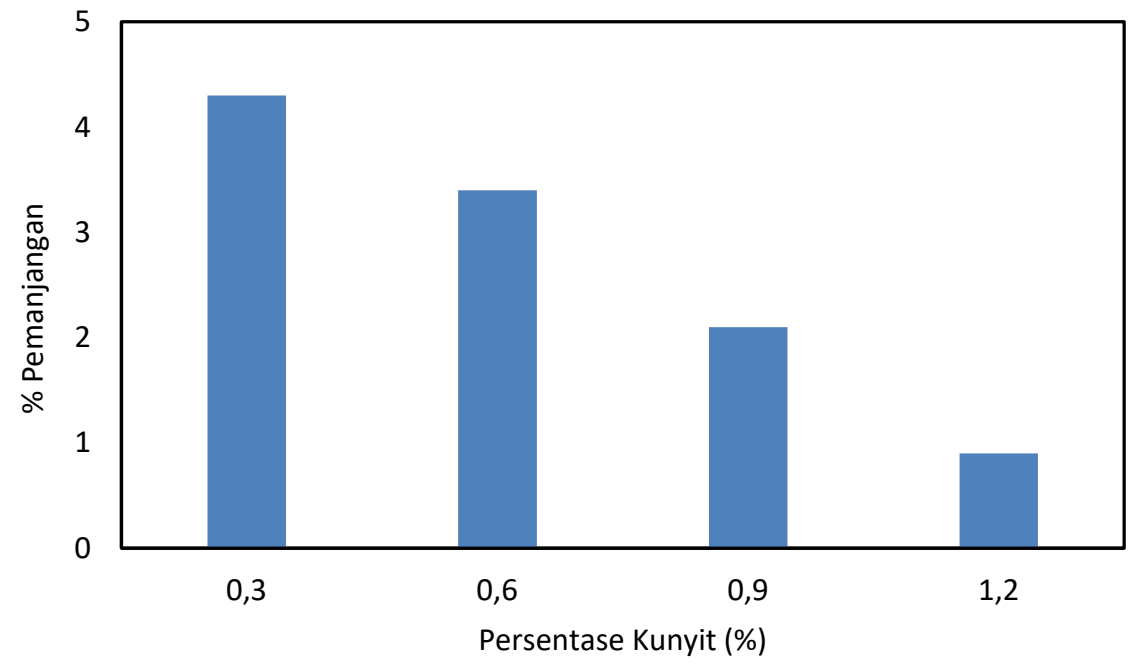

Gambar 3. Persentase Kemuluran Film berbagai variasi penambahan kunyit 
Uji kemuluran (elongation at break) atau proses pemanjangan merupakan perubahan panjang maksimum pada saat terjadi peregangan hingga sampel film terputus. Dengan uji kemuluran ini, dapat diketahui tingkat penambahan panjang bahan (Puwati, 2010). Gambar 3 menunjukkan efek persentase banyaknya kunyit yang berada dalam bioplastik kitosan-pati onggok aren terhadap kemuluran bioplastik.

Peningkatan banyaknya kunyit dalam bioplastik menyebabkan penurunan kemuluran, artinya plastik yang dihasilkan semakin mudah patah (Gambar 3.) Persentase kemulurannya pada nilai 4,3\% pada bioplastik dengan kandungan kunyit $0,3 \%$ menjadi $0,9 \%$ kemuluran pada biolplastik dengan kandungan kunyit 1,2\%.

\subsection{Uji Biodegradasi}

Biodegradasi merupakan salah satu parameter yang dapat menunjukkan bahwa tingkat kemudahan bioplastik terbiodegradasi sehingga dapat digolongkan menjadi material yang ramah lingkungan. Uji biodegradasi dilakukan untuk mengetahui seberapa cepat plastik terdegradasi oleh mikroorganisme di suatu lingkungan. Media yang digunakan adalah tanah karena di dalam tanah terdapat banyak jenis mikroorganisme (jamur, bakteri dan alga) dan dalam jumlah yang banyak pula, sehingga akan menunjang proses degradasi yang akan dilakukan (Apriani dan Sedyadi, 2015).

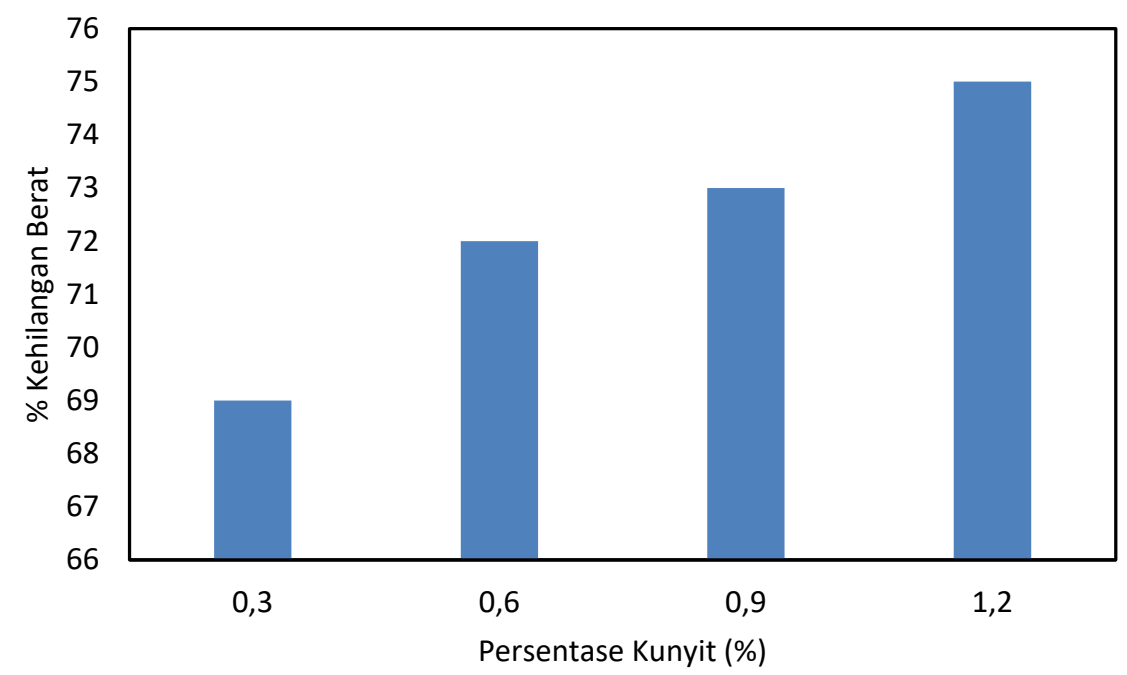

Gambar 4. Persentase Biodegradasi Film berbagai variasi penambahan kunyit

Gambar 4 adalah data yang menunjukkan massa yang hilang setelah bioplastik ditanam dalam tanah selama 4 minggu. Secara umum peningkatan banyaknya serbuk kunyit dalam plastik kitosan-pati onggok meningkatkan jumlah massa yang hilang karena proses degradasi. Hasil uji ini menyimpulkan bahwa bioplastik yang terbuat dari kitosan, pati onggok aren dan tambahan serbuk kunyit menghasilkan plastik yang mudah terdegradasi.

\section{Kesimpulan}

Dari penelitian yang telah dilakukan tentang karakteristik onggok aren (arenga pinnata) dengan penambahan serbuk kunyit dapat disimpulkan bahwa nilai kuat tarik dipengaruhi oleh banyaknya serbuk kunyit dengan nilai terbesar pada penambahan 1,2\% yaitu 10,3 Mpa. Hasil uji ketahan air menunjukan bahwa film dengan penambahan kunyit 1,2\% memiliki nilai ketahanan air tertinggi yaitu $92 \%$. Sedangkan untuk uji kemularan menunjukan bahwa film dengan penambahan kunyit 0,3\% memiliki nilai elongasi tertinggi sebesar 4,30\%. Sedangkan untuk hasil uji biodegradasi menunjukan bahwa film bioplasik dengan penambahan kunyit mengalami degradasi dalam waktu kurang lebih 4 minggu dengan hasil penambahan kunyit 1,2\% memiliki nilai degradasi sebesar $75 \%$. Dengan penambahan variasi serbuk kunyit pada bioplastik dapat meningkatkan sifat karakteristik bioplastik. Sehingga, bioplastik yang terbuat dari kitosan, tepung pati onggok aren dan kunyit layak untuk dikembangkan sebagai plastik yang ramah lingkungan, meskipun penelitian lanjutan masih perlu dilakukan. 


\section{Referensi}

[1] Agustin, Y. E., \& Padmawijaya, K. S. (2016). "Synthesis of Chitosan-Pati Bioplastics Kepok Banana," Jurnal Teknik. Kimia, 10(2), pp. 40-48.

[2] Coniwanti, P., Laila, L., \& Alfira, M. R. (2014). "Pembuatan Film Plastik Biodegredabel dari Pati Jagung dengan Penambahan Kitosan Dan Pemplastis Gliserol," Jurnal Teknik Kimia, 20(4), pp. 22-30.

[3] Nurlita, D., Wikanastri, H., \& Yusuf, M. (2017). "Karakteristik Plastik Biodegradable Berbasis Onggok dan Kitosan dengan Plastisizer Gliserol," Jurnal Pangan Dan Giri, 7(2).

[4] Abugoch, L. E., Tapia, C., Villamán, M. C., Yazdani-Pedram, M., \& Díaz-Dosque, M. (2011). "Characterization of quinoa protein-chitosan blend edible films," Food Hydrocolloids, 25(5), pp. 879-886.

[5] Aprianda, R., Fachraniah, \& Rihayat, T. (2018). "Pemanfaatan Kitosan sebagai Biofilm dengan Penambahan Turmeric Essential Oil untuk Meningkatkan Aktivitas Antibakteri," Prosiding Seminar Nasional Politeknik. Negeri Lhokseumawe, 2(1), pp. 221-225.

[6] Darni, Y., \& Utami, H. (2009). "Studi Pembuatan dan Karakteristik Sifat Mekanik dan Hidrofobisitas Bioplastik dari Pati Sorgum," Jurnal Rekayasa Kimia \& Lingkungan, 7(2), pp. 1-1.

[7] Darni, Y., Sitorus, T. M., \& Hanif, M. (2014). "Produksi Bioplastik dari Sorgum dan Selulosa Secara Termoplastik," Jurnal Rekayasa Kimia \& Lingkungan, 10(2), pp. 55-62.

[8] Purwanti, A. (2010). "Analisis Kuat Tarik dan Elongasi Plastik Kitosan Terplastisasi Sorbitol," Jurnal Teknologi, 3(2), pp. 99-106.

[9] Apriyani, M dan Endaruji S. (2015). "Sintesis dan Karakterisasi Plastik Biodegradable dari Pati Onggok Singkong dan Ekstrak Lidah Buaya ( Aloe vera ) dengan Plasticizer Gliserol," Sain Dasar, 4(2), pp. 145152. 